\title{
BIOETHANOL FROM STRAW AND ITS PUBLIC ACCEPTANCE
}

\begin{abstract}
Alexander JÄGER, Faculty of Engineering, University of Applied Sciences Upper Austria, Stelzhamerstr. 23, 4600 Wels Austria. a.jaeger@fh-wels.at (corresponding author)

Heike KAHR, Formerly Faculty of Engineering, Formerly University of Applied Sciences Upper Austria, Stelzhamerstr. 23, 4600 Wels Austria. heike.kahr@liwest.at

Tina ORTNER, Faculty of Social Sciences, University of Applied Sciences Upper Austria, Garnisonstr. 21, 4020 Linz, Austria. t.ortner@fh-linz.at

Renate KRÄNZL-NAGL, Faculty of Social Sciences, University of Applied Sciences Upper Austria, Garnisonstr. 21, 4020 Linz,

Austria. renate.kraenzl-nagl@fh-linz.at

The consequences of global warming and the need for a reduction in greenhouse gases have led to dramatic changes in the automotive sector. Whereas the use of biofuel increased continuously over the first decade of this century, e-mobility has been deemed.by politicians and the media alike. As the development of the electric car, rechargeable batteries and charging stations are far from being fully explored, biofuels will play an important role as a bridging technology over the next 20 years. The successful use of biofuels requires its widespread acceptance by consumers. To evaluate the public opinion towards biofuels we carried out a representative opinion poll to collect information on the population's acceptance of biofuels. The result indicates that there is a lack of interest and information about biofuels, especially among young people and women. First generation bioethanol is strongly associated with the waste of food, but the acceptance of the second generation, produced from agricultural remnants like straw from wheat or corn, is considerably higher. The interviewees see more transparent, objective and less technical information about biofuels as an essential way to increase the level of information and the acceptance rate. In summary, the introduction of biofuels must be accompanied by information campaigns if biofuels should ever reach larger market shares. The irritations caused by the manipulation of the software on the part of several automobile manufacturers of Diesel engines could pave the way for this. So, future decentralized bioethanol plants could play an important role in biofuel production and contribute to the development of rural areas. In this paper the legal aspects of biofuel usage are described, the State of the art Bioethanol production from lignocellulosic material is described, the production capacity worldwide is calculated and the results from an opinion poll concerning the public acceptance of biofuels are presented.
\end{abstract}

Keywords: Advanced Biofuels, Bioethanol, lignocellulose; opinion poll, public acceptance

\section{INTRODUCTION}

Renewable energies and especially biofuels play an important role to ensure energy sustainability. Due to the increasing dependency on crude oil imports, and increasing greenhouse gas emissions, it is important to think about alternatives. Bioethanol or biodiesel represent the most promising technical approaches because they can be blended with fossil fuels (gasoline or diesel), and they can be used in existing combustion engines without major changes (Gnansounou, 2010). First generation bioethanol (derived from sugar cane or starchy crops) is produced worldwide by fermentation. The world bioethanol production was over 100 billion liters in 2015 (calculated from Renewable Fuel Association, 2017). In Austria crops like wheat and maize are used for this process (Kahr et al., 2013). Because these are potentially food or animal feed, the population often links the usage of this bioethanol to food wasting. In addition concerns about direct and indirect effects on land use change (ILUC) were caused. Thus the bioethanol production of the $1^{\text {st }}$ generation is critically regarded by the public and the print media, worrying price increases and food shortages. Meanwhile research on advanced biofuels like second generation bioethanol made great progress. It can be produced from a wide range of feedstock including agricultural residues, which do not compete directly with the cultivation of food crops (Lichtscheidl et al., 2013). The technology for the production of the bioethanol $2^{\text {nd }}$ generation is now available and the first production plant with a capacity of 50.000 tons per year is in operation (Kahr et al., 2013). The sustainable production of bioethanol from lignocellulose biomass is expected to become a credible alternative within a few years. Nevertheless biofuels only play still a minor role in the European transport sector. One reason is the poor acceptance of biofuels in the population and political scene (Ortner et al., 2013).

Legal aspects of biofuel usage are summarized as follow. 1997 EC White Paper 'Energy for the future recognized biofuels as a renewable source of energy. A possible 18 million tons liquid biofuels in 2010 was mentioned as well as a possibility to improve emissions caused by transport. The Directive 2003/30EC on the promotion of the use of biofuels

Copyright (C) 2017 The Authors. Published by Aleksandras Stulginskis University. This is an open-access article distributed under the terms of the Creative Commons Attribution License (CC-BY 4.0), which permits unrestricted use, distribution, and reproduction in any medium, provided the original author and source are credited. 
for transport requested that member states should ensure that a minimum proportion of biofuels and other renewable fuels are placed on the markets. A reference value for these targets was set to be $2 \%$ by $31^{\text {st }}$ of December 2005 and $5.75 \%$ by $31^{\text {st }}$ of December 2010. The Directive 2009/28/EC set $10 \%$ target for renewable energy sources in transport for the year 2020. In 2015 the DIRECTIVE (EU) 2015/1513 capped the amount of biofuels and bioliquids produced from "food crops" like cereals, other starch- rich crops, sugars and oil crops at $7 \%$ for the year 2020 . The other $3 \%$ should come from a variety of alternatives like biofuels from used cooking oil and animal fats or bioethanol from straw. Among all this advanced biofuels production possibilities, only bioethanol derived from straw is produced at an industrial scale.

State of the art Bioethanol production from lignocellulosic material. Feedstock used for second generation bioethanol production - also called advanced biofuels - are mainly lignocellulose-containing raw materials like straw from wheat and maize but also other plants like arundo donax or miscanthus sinensis or hay. The first plant in the world to produce bioethanol from agricultural residues and energy crops at a commercial scale was opened 2013 near the city of Crescentino in Italy by the company Beta Renewables. The design capacity is 50 million liters of cellulosic ethanol annually from "agricultural waste" like arundo donax, rice straw and other. Among other installations the POET/DSM bioethanol plant in Liberty Emmetsburg, Iowa, USA is another example of the possibility to produce bioethanol from straw at an industrial scale. It is located in the US corn belt and is integrated within a conventional first generation bioethanol plant (feedstock maize). Maize stover is converted into bioethanol by the "classical" technology scheme: shredding - pretreatment - enzymatic hydrolysis - fermentation - distillation. In summary the technology to convert a large variety of agricultural residues into bioethanol is not only state of the art but already state of the technology.

Production capacity Bioethanol: The worldwide production volume of first generation bioethanol (feedstock mainly sugar cane, wheat and maize) was 58.72 million tons crude oil equivalents in 2009 . The main producers were the USA (31.86 million tons) and Brazil (19.77 million tons). The production capacity of bioethanol was only $1 \%$ (energy) of the world oil production and $6.8 \%$ of the global fuel consumption.

The production potential of the bioethanol second generation (from straw) was calculated in 2 ways: The first calculation took only into account the utilization of straw from crops. A theoretical yield from straw to bioethanol of $95 \%$ was assumed resulting in $245 \mathrm{~kg}$ ethanol per ton of straw. For the second calculation the straw from crops and harvest residues from oil seeds and sugar cane (Bagasse) were included. The quantity of straw was calculated using a grain / straw ratio. The total straw quantity was 2284 million tons in 2009 with rice straw making up $36 \%$ (819 million tons) maize stover (straw) $33 \%$ and straw from wheat $24 \%$ (Schürz, 2012). The ethanol production potential was calculated using $25,50,75$ und $100 \%$ of the total straw. If $25 \%$ of the produced straw is utilised for production of bioethanol 140 million tons of ethanol could be produced (Table 1). If $50 \%$ of the straw would be used, 280 million tons of ethanol or 180 million tons of crude oil equivalent could be delivered to the markets. A utilization rate of $50 \%$ is regarded as a realistic scenario.

Table 1. Bioethanol from straw

\begin{tabular}{ccccc}
\hline $\begin{array}{c}\text { utilisation rate } \\
\text { straw }\end{array}$ & $\begin{array}{c}\text { Straw } \\
\text { Mio. to }\end{array}$ & $\begin{array}{c}\text { Ethanol } \\
\text { Mio. to }\end{array}$ & $\begin{array}{c}\text { Oil equivalent } \\
\text { Mio. to }\end{array}$ & $\begin{array}{c}\text { Substitution } \\
\text { rate } \%\end{array}$ \\
\hline $25 \%$ & 571 & 140 & 90 & 16 \\
$\mathbf{5 0 \%}$ & $\mathbf{1 1 4 2}$ & $\mathbf{2 8 0}$ & $\mathbf{1 7 9}$ & $\mathbf{3 2}$ \\
$75 \%$ & 1713 & 420 & 269 & 48 \\
$100 \%$ & 2284 & 560 & 358 & 65 \\
\hline
\end{tabular}

The actual fuel consumption worldwide accounts to 555 million tons crude oil equivalent. Thus about a third of the fuel could be replaced by biofuel from straw converting $50 \%$ of the straw to bioethanol.

If in addition the feedstock straw bagasse from sugar cane and the lignocellulosic residues from oil the seeds would be converted into bioethanol a further increase in the production potential would result (Table 2). The ethanol yields would increase so that $89 \%$ of the straw would be necessary to replace conventional fuel completely by biofuel from straw. This data show that a complete replacement of fossil fuels would be possible with the technology already available.

Table 2: Bioethanol from straw, bagasse and oil seed residues

\begin{tabular}{crccc}
\hline Utilisation rate & Straw Mio. to & Ethanol Mio. to & Oil eq. Mio. to & Substitution rate \% \\
\hline $25 \%$ & 992 & 243 & 155 & 28 \\
$50 \%$ & 1983, & 468 & 311 & 56 \\
$75 \%$ & 2975 & 729 & 466 & 84 \\
\hline $\mathbf{8 9 \%}$ & $\mathbf{3 5 3 1}$ & $\mathbf{8 6 5}$ & $\mathbf{5 5 4}$ & $\mathbf{1 0 0}$ \\
\hline $100 \%$ & 3967 & 972 & 622 & 112 \\
\hline
\end{tabular}

The problems and discourse concerning the introduction of bioethanol mainly in Europe showed that the introduction of biofuels and bioethanol in particular can fail dramatically if the population is not well informed. This can lead to the generation of a negative opinion regarding the usage of bioethanol. The government of the Federal Republic of Germany for instance increased the proportion of bioethanol in petrol up to $10 \%$ in January 2011. The introduction failed and led to an uproar because the population was not informed enough. Therefore, we carried out a representative opinion poll to gather information on the acceptance of bioenergy in general and bioethanol specifically in Austria. 


\section{RESEARCH METHODOLOGY}

Opinion Poll: The area examined was the state of Upper Austria, located in the northern part of Austria which has about 1.5 million inhabitants. The state is characterized by a highly industrialized energy intensive centre on one side (580 000 inhabitants) and an agricultural, hilly area on the other side. Farmers are looking for new business segments like bioenergy production (wood, biogas, biodiesel). Upper Austria claimes to be the heart of pellet stove production in central Europe.

For the survey, a stratified sample was chosen to guarantee that the percentage of the stratums in the population was the same as in the sample (Raab-Steiner and Benesch, 2008). 603 telephone interviews were carried out in total with a duration of about 15 minutes each. (302 female, 301 male, 201 age 16 -39, 201 age 30-49. 301 age 50+, to give a representative cross-section of the population of upper Austria). Only selected results of the poll are presented in this paper. The first part of the interviews was about renewable energies in general. It focused on the knowledge and people's attitudes concerning renewable energies. The second part dealt with biofuels and bioethanol in particular. The respondents had to explain different terms, such as biofuel, bioethanol and E10. The focus in the third part of the questionnaire was on the image and the perceived difference of $1^{\text {st }}$ and $2^{\text {nd }}$ generation bioethanol. The respondents were faced with different statements and had to evaluate them according to their opinion. Finally, they had to state their opinion concerning future developments in the biofuel sector.

\section{RESULTS AND DISCUSSION}

Results opinion poll: Information level: $86 \%$ of the people questioned knew the term biofuel. The term bioethanol was known by two thirds of the people questioned. The goal of the EC to raise the use of energy from renewable sources in the transport sector to a minimum of $10 \%$ in every member state until 2020 was known by $50 \%$ of the population. Just as many have heard about the term E10, but only two out of five knew that the present addition of bioethanol to fuel is $5.75 \%$ in Austria. The result also shows that men are better informed about biofuel related topics than women. Biofuels were most frequently associated with biodiesel and with oil plants like rape and sunflowers. The association with edible agricultural products is ranked in third place. Fewer people, namely less than $10 \%$, connect biofuels to (bio-) ethanol. Bioethanol itself is strongly linked to alcohol made out of edible agricultural products like maize and sugar beet. Around 405 of the persons who have knowledge about bioethanol in general, cannot associate anything with this term. This result reflects the low interest of Upper Austrians the introduction of bioethanol as alternative energy source. Hence, only a third of the interviewed persons is interested in bioethanol, which is a very low number compared to the $90 \%$ who show interest in renewable energy in general. Only 2 out of 5 people feel well informed about this topic. E10 is explained as a $10 \%$ addition of bioethanol. To the term E10 the people mentioned very few negative associations and explained the term objectively.

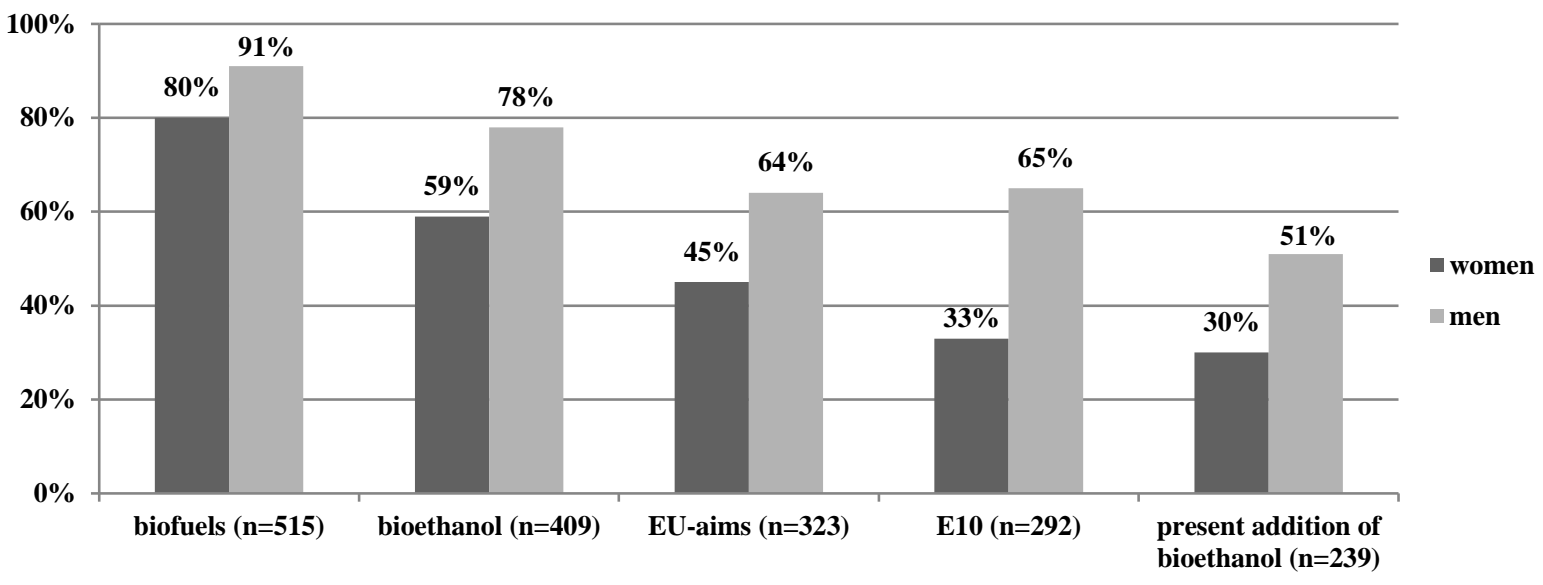

Figure 1. Information level on different terms and strategies

Opinion about first and second generation bioethanol. To find out the prevailing image of bioethanol, the respondents could agree or disagree with 8 statements shown in Figure 1. The results indicate that most people, nearly two thirds, agreed that bioethanol made out of maize is untenable to use as fuel. The amount of agreements increased proportionally with the age of the people - meaning elderly people more often have this opinion. About half of the population thought that the use of E10 (10\% Ethanol $90 \%$ gasoline) reduces the dependency on oil and on oil producing countries. Among the male respondents $60 \%$ had this opinion, whereas only $47 \%$ of the women agreed with this statement. $50 \%$ of the population had the opinion that E10 is no future alternative to conventional fuel and once again more men than women thought so. About a third of the people had the opinion that E10 is good for the climate with more male and young people having this view. In comparison, about a third had the differing opinion that E10 is not environmentally friendlier compared to conventional fuel. The opinion poll also showed that about a third of the people questioned admitted that they strictly support the idea of the addition of $10 \%$ ethanol to gasoline (E10), but $30 \%$ thought 
that E10 harms the engines of cars. The fact that E10 is cheaper than conventional fuel is agreed upon by about $45 \%$ of the population. It can be suspected that the Austrians are not well informed about the compatibility of E10 with their cars, because E10 has not yet been introduced in Austria.

Women in general were less informed about bioethanol than men. With regard to age younger people in particular were less critical to the image of biofuels and were more often proponents. This result was also reflected in the question about the readiness to fill up one's car with E10. Only 10\% of the respondents were definitely sure about using E10 and $22 \%$ thought that they might fill up the car with E10. In summary, $44 \%$ of people under 30 years of age could imagine to use E10, whereas only $23 \%$ of the people over 50 years of age had this attitude as shown in Figure 2.

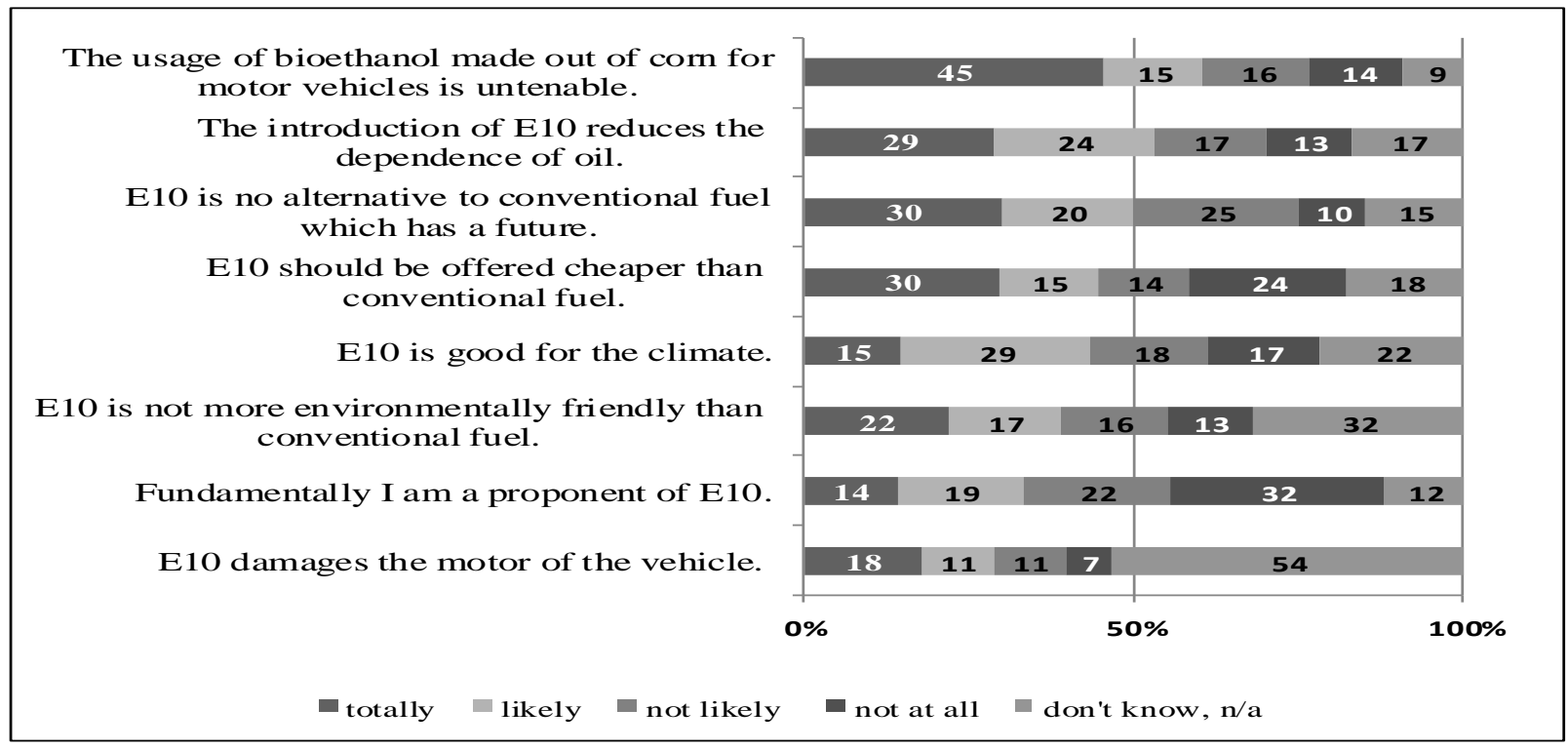

Figure 2. Image of bioethanol ( $\mathrm{n}=603$ each row)

A very interesting aspect of the survey was the different attitude towards bioethanol of the first and second generation. Figure 3 shows that the respondents distinguish strongly between these two different kinds of bioethanol. 80 $\%$ of the people in Upper Austria would prefer to use bioethanol made out of agricultural residues like straw rather than bioethanol made out of potential food. To $37 \%$ of the people questioned it made no difference. 4 out of 5 people supported the opinion that research on advanced biofuels like bioethanol of the 2nd generation should be supported. About $40 \%$ did not see it as an alternative to conventional gasoline or diesel.

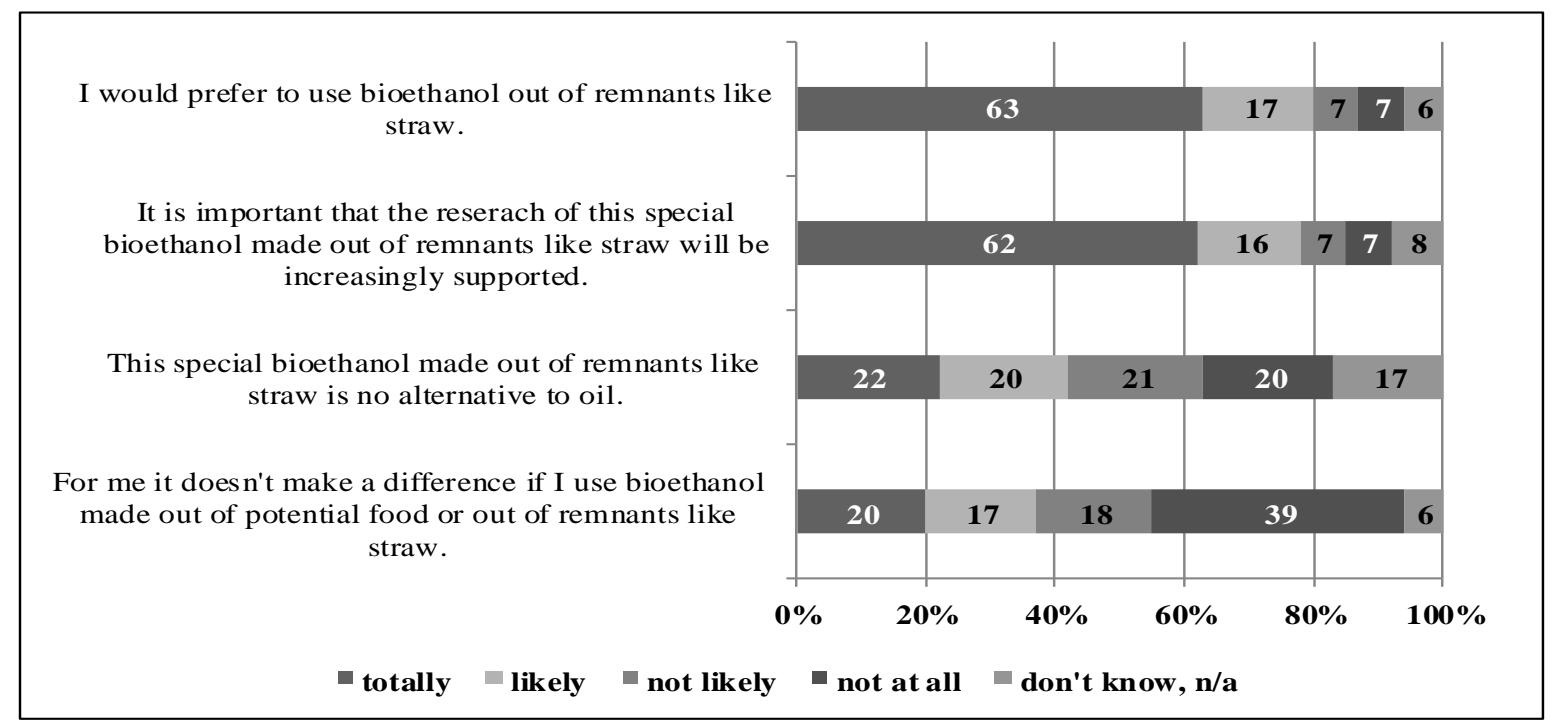

Figure 3. Image of second generation bioethanol ( $\mathrm{n}=603$ each row)

\section{CONCLUSION AND DISCUSSION}

The paper shows that the technology for bioethanol production from lignocellulose materials is already available nowadays. Several production plants have been constructed and may be in operation depending on market prices of fossil gasoline. Our calculations showed that a complete replace would be conceivable if $89 \%$ of the available straw and other lignocellulosic materials like bagasse would be converted into bioethanol, indicating that it should be possible to introduce 
a larger proportion into the market. In contrast to this possibility, the public opinion and the communications from the European commission do not show euphoria with biofuels. The opinion poll shows that especially first generation bioethanol and E10 have a bad image in Upper Austria. In comparison to the first generation, the second generation bioethanol has a much higher acceptance rate. We conclude that under certain circumstances (higher prices of fossil fuels) such as instability and insecurity of energy supply, a large proportion of fuels for the transport sector would originate from lignocellulosic material. The irritations caused by the manipulation of the software of Diesel engines on the part of several automobile manufacturers could pave the way for an introduction of biofuels like ethanol from straw at a much larger scale. To increase the acceptance for biofuels further, we suggest the construction of decentralized bioethanol plants within agricultural regions. The bioethanol produced there should only be concentrated up to $98 \%$ vol. ethanol. The last (costly) step of the downstream process - dewatering up to $99.9 \%$ vol. - could be done in a central bioethanol production and distribution facility or in an existing conventional refinery.

\section{ACKNOWLEDGEMENT}

The work was financed by the project "Strohethanol" within the scope of the European Union Program 'Regionale Wettbewerbsfähigkeit OÖ 2007-2013 (Regio 13)' from the purse of the European Funds for Regional Development (EFRE) and the Federal State of Upper Austria, Austria.

\section{REFERENCES}

1. Directive 2009/28/EC - promoting the use of energy from renewable sources 2009. http://eur-lex.europa.eu/legalcontent/EN/TXT/?uri=LEGISSUM\%3Aen0009 (accessed on 11/10/2017)

2. Directive (EU) $2015 / 1513$ of the European Parliament and of the Council 2015. http://eur-lex.europa.eu/legalcontent/EN/TXT/PDF/?uri=CELEX:32015L1513\&from=DE (accessed on 11/10/2017)

3. ENERGY FOR THE FUTURE, 1997. White Paper for a Community Strategy and Action Plan COM(97)599 final (26/11/1997) http://europa.eu/documents/comm/white_papers/pdf/com97_599_en.pdf (accessed on 11/10/2017)

4. Gnansounou, E. 2010. Production and use of lignocellulosic bioethanol in Europe: Current situation and perspectives. Bio resource Technology. Vol. 101, Iss. 13, pp. 4842-4850. https://doi.org/10.1016/j.biortech.2010.02.002

5. Kahr, H., Wimberger, J., Schürz, D., Jäger A. 2013. Evaluation of the Biomass Potential for the Production of Lignocellulosic Bioethanol from Various Agricultural Residues in Austria and Worldwide. Energy Procedia. Vol. 40, pp. 146-155. https://doi.org/10.1016/j.egypro.2013.08.018

6. Lichtscheidl, J., Buchsbaum, A., Maly, M. 2013. The EU's Roadmap to a Low-Carbon Economy - Aspirations and Realities for Refiners OIL GAS. European Magazine. No. 2, pp. 88-91.

7. Ortner, T., Kränzl-Nagl, R., Kahr, H. 2013. The Acceptance of Biofuels and Bioethanol - Results of an Opinion Poll. 8th Conference on sustainable development of Energy, Water and Environ. systems, Dubrovnik, Croatia, p. 214.

8. POET / DSM 2015 http://poetdsm.com/pr/poet-dsm-plans-on-site-enzyme-mfg-at-liberty (accessed on 11/10/2017)

9. Raab-Steiner, E., Benesch, M. 2008. Der Fragebogen. Von der Forschungsidee zur SPSS-Auswertung. Facultas Verlag, Vienna 1st edition, ISBN 978-3-8252-8607-1

10. Renewable fuel association 2017. http://www.ethanolrfa.org/resources/industry/statistics/\#1454099103927-12.61e598f7-7643 (accessed on 11/10/2017)

11. Schürz, D. 2012. Weltweites Bioethanolpotential aus Biomasse der zweiten Generation. Master Thesis University of Applied Sciences Upper, Austria, p. 28. 